\title{
Pengaruh Internal Branding pada Customer Based Brand Equity dengan Mediasi Loyalitas Organisasi
}

\author{
Veny Vironika ${ }^{1}$, M.N. Reza Pradana ${ }^{2}$ \\ *Universitas Universal, Faculty of Management \\ Kompleks Maha Vihara Duta Maitreya, Bukit Berumtung, Sei Panas, Batam 29456 \\ Email: venyding@gmail.com
}

\begin{abstract}
Abstrak
Branding telah menjadi bagian dari keunggulan kompetitif setiap perusahaan. Tujuan penelitian ini untuk mengukur sejauh mana pengaruh internal branding pada customer based brand equity dan efek mediasi loyalitas organisasi pada toko-toko ritel yang berkembang di kota Batam. Penelitian ini menggunakan data kuesioner yang dikumpulkan dari karyawan front-line dan pelanggan dari toko ritel tertentu dengan purposive sampling. Analisis kolerasi, mediasi dan teknik analisis data uji t sampel independen diterapkan melalui smartPLS dan SPSS. Hasil penelitian mengungkapkan bahwa internal branding mempengaruhi customer based brand equity secara langsung tanpa memerlukan loyalitas organisasi sebagai variabel mediasi. Hasil ini dapat membantu sektor industri toko ritel dengan bukti empiris untuk menerapkan internal branding di organisasi mereka untuk menciptakan ekuitas merek antara toko dan pelanggan melalui karyawan front-line. Kontribusi penting studi ini terhadap dunia industri dan akademik adalah dukungan empirisnya untuk hubungan antara IB dan CBBE pada toko ritel di kota Batam.
\end{abstract}

Kata kunci : Branding, internal branding, customer based brand equity, toko ritel, loyalitas organisasi.

\begin{abstract}
Branding has become part of every company's competitive advantage. The purpose of this study is to measure the influence of internal branding on customers based on brand equity and the mediating effect of organizational loyalty in developing retail stores in Batam City. This study uses questionnaire data collected from front-line employees and customers from certain retail stores by purposive sampling. Collaboration analysis, mediation and independent sample t-test data analysis techniques were applied through smart PLS and SPSS. The results revealed that internal branding directly affected customer brand equity without requiring organizational loyalty as a mediating variable. This result could help the retail store industry sector by proving empirically to implement internal branding in their organizations to create brand equity between stores and customers through the front line employees. The study's noteworthy contribution to the industrial and academic world is the empirical support for the relationship between $I B$ and CBBE in retail stores in Batam City.
\end{abstract}

Keywords : Branding, internal branding, customer based brand equity, retail stores, organizational loyalty.

\section{Pendahuluan}

Branding telah menjadi salah satu kunci sukses dalam meningkatkan keunggulan kompetitif dalam melakukan usaha. Saat ini, Brand (merek) bukan hanya sekedar logo dari sebuah perusahaan tetapi juga merupakan perwakilan dari jumlah persepsi orang tentang bagaimana layanan pelanggan, reputasi, iklan, dan citra perusahaan di hadapan publik (Deluxe, 2015). Brand dari bisnis cenderung sehat dan kuat jika fungsi-fungsi perusahaan dapat bekerja dengan baik secara maksimal. Berdasarkan Small Business Resource Centre, Brand yang kuat dapat meningkatkan pengakuan, kepercayaan dan menarik perhatian pelanggan, menghasilkan pelanggan baru serta menginspirasi karyawan dalam membangun finansial usaha (Deluxe, 2015).

Maraknya perkembangan pemasaran industri meningkatkan kesadaran orang akan peran penting brand. Brand tidak lagi hanya dikembangkan untuk produk atau jasa dan merek korporat, tetapi brand juga dapat dikembangkan untuk karyawan perusahaan di bidang manajemen sumber daya manusia (Backhaus dan Tikoo, 2004; Punjaisri dan Wilson, 2017). Brand yang digunakan dan diterapkan pada manajemen sumber daya manusia 29 | Jurnal Akuntansi, Ekonomi dan Manajemen Bisnis | Vol. 8 No.1, July 2020, 29-38 | E-ISSN: 2548-9836 
suatu organisasi dikenal sebagai internal branding (Aurand et al., 2005; Hasni et al., 2018). Penelitian Sullivan (2004) berpendapat bahwa banyak organisasi yang menggunakan internal branding (IB) untuk menarik calon karyawan potensial dalam menyampaikan pesan positif tentang organisasi perusahaan.

Penelitian Du Preez dan Bendixen (2015) menyatakan bahwa organisasi yang mengedepankan IB mampu meningkatkan loyalitas organisasi (OL/Organization Loyalty) dan keberlanjutan kerja, mendorong karyawan untuk memberikan pelayanan yang lebih baik, karena kepemahaman mereka terhadap makna brand yang digunakan lebih mendalam, dan mendorong karyawan untuk bekerja lebih baik. IB produk barang dan jasa pada dasarnya sama dalam fokus untuk membangun dan meningkatkan ekuitas merek serta membangun hubungan yang kuat antara merek dan pelanggannya (Kimpakorn dan Tocquer, 2010). Hubungan asosiasi yang timbul antara merek dan pelanggannya dikenal sebagai ekuitas merek berbasis pelanggan (CBBE/Customer-Based Brand Equity (Keller 2016; Schultz et al. 2013).

Beberapa penelitian terdahulu menilai program manajemen IB yang sukses akan menghasilkan karyawan lini depan yang mampu mengkomunikasikan brand saat berinteraksi dengan pelanggan (Du Preez dan Bendixen, 2015). Internal Branding yang sukses diterapkan dapat meningkatkan kecocokan karyawan dengan lingkungan kerja dan meningkatkan pengetahuan merek karyawan (Boukis et al., 2017). Penelitian Utami (2015) menjelaskan keberhasilan program internal branding Bank Mandiri dinilai melalui kinerja merek, seperti penjualan, brand recall, dan ekuitas merek, serta indikator kepuasan, pemahaman dan komitmen antara karyawan. Selain itu, organisasi juga memiliki peranan dimana karyawan menerima atau mengabaikan pesan merek yang harus disampaikan (Boukis et al., 2017; Löhndorf dan Diamantopoulos, 2014).

Penelitian lainnya yang mengabaikan konteks IB, seperti penelitian King dan Grace (2008) menilai tidak ada nilai tambah dari IB yang terkandung dalam sumber daya organisasi dan hubungan antara ekuitas berbasis karyawan atau Employee-Based Brand Equity dengan CBBE harus dikedepankan. Konsep CBBE dalam literatur juga dibahas secara terpisah dengan mengabaikan hubungannya dengan sisi karyawan. Penciptaan merek yang kuat dan penyampaian kualitas layanan yang dirasakan oleh pelanggan didasarkan pada kemampuan karyawan (Mude et al., 2012).

Penelitian tentang IB kebanyakan dilakukan di daerah yang sudah maju. Konsep IB juga berkembang di kota Batam. Industri ritel di kota Batam merupakan salah satu sektor yang tumbuh pesat dalam beberapa tahun terakhir khususnya setelah kehadiran Indomaret dan Alfamart pada tahun 2014, UNIQLO lifewear dan H\&M pada tahun 2019. Hal ini ditunjukkan oleh angka pertumbuhan ekonomi bidang perdagangan besar dan eceran, reparasi mobil dan sepeda motor secara global pada triwulan III tahun 2019 Provinsi Kepulauan Riau dalam laporan Berita Resmi Statistik BPS tercantum sebesar 9,39\% dibawah Industri Pengolahan, Konstruksi, Pertambangan dan Penggalian. Dan pertumbuhan ekonomi kota Batam berdasarkan laporan Badan Pusat Statistik Provinsi Kepulauan Riau 2019 mencapai 4,72\% lebih tinggi dari tahun sebelumnya yang hanya mencapai 4,5\%. Jumlah Usaha Mikro Kecil dan Menengah (UMKM) ritel di Kota Batam berdasarkan data Online Data Sistem (ODS) di Kementerian Koperasi UKM RI sebesar 81.486 usaha (Sebayang, 2019).

Meskipun pernah terjadi penurunan ekonomi sektor ritel seperti tutupnya operasi Giant pada tahun 2018, berhentinya Gelael Signature cabang Baloi yang beroperasi sejak awal 2000-an dan bersatu dengan ritel sejenis di Palm Springs Batam (Dodo, 2019). Menurut pengamat ekonomi dari Universitas Internasional Batam, Suyono Saputro mengakui bahwa perekonomian di Batam sempat mengalami penurunan pada tahun 2018, namun itu tidak lantas menjadi penyebab tutupnya usaha ritel (Dodo, 2019). Penyebab tutupnya usaha ritel menurut Suyono Saputra disebabkan oleh dua hal, yaitu perubahan pola konsumsi masyarakat dan ketatnya persaingan ritel di Batam.

Maka dari itu, penelitian ini bertujuan untuk menguji kembali pengaruh internal branding pada Customer-based brand equity dengan mediasi loyalitas organisasi pada usaha ritel di kota Batam sesuai dengan jurnal peneliti terdahulu (Hasni et al., 2018) mengenai variabel yang sama di kota yang berbeda. Penelitian ini menjelaskan hubungan antara praktik internal branding pada usaha ritel di kota Batam dan hasilnya pada ekuitas eksternal, yaitu Customer-based brand equity. Penelitian ini diharapkan dapat meningkatkan pertumbuhan ekonomi industri ritel kota Batam dan mengurangi ancaman tutupnya usaha ritel dengan memaksimalkan Customer-based brand equity karena setiap bisnis perlu mengembangkan strategi yang kreatif dan kompetitif untuk menguatkan hubungan perusahaan dengan pelanggannya.

\section{Tinjauan Pustaka}

Penelitian ini menggunakan berbagai teori dalam menjelaskan alasan di balik pengaruh IB pada CBBE dengan efek mediasi dari OL di Kota Batam. Teori tersebut antara lain ; teori keseimbangan (Heider, 2013), teori penularan emosi (Hatfield et al., 1993), teori kontrak psikologis (Hendry dan Jenkins, 1997), dan teori Naive Psychology Heider (2013). 
Teori keseimbangan (Heider, 2013) menjelaskan tentang usaha individu dalam mempertahankan keteraturan perusahaan, karyawaan, dan pelanggan. Teori ini mengintegrasikan IB, CBBE, dan OL yang ditunjukkan oleh hubungan antara pelanggan, karyawan dan organisasi. Karyawan menerima panduan branding dari pihak manajemen dan kemudian memperlihatkan hasil pekerjaan mereka yang unggul untuk mencapai kinerja dan produktivitas perusahaan.

Sebagai pendukung teoretis terhadap kerangka penelitian ini, teori penularan emosi (Hatfield et al., 1993) mendukung hubungan antara employer brand equity dan customer brand equity, berdasarkan pada bagaimana efek dan perasaan dihubungkan di antara manusia, untuk membentuk ikatan yang kuat antara ekuitas penjual dan pembeli. Teori ini menemukan bahwa setiap individu membandingkan perilakunya dengan orang lain dan menyesuaikan tingkat emosionalnya. Dengan demikian, ketika seorang karyawan menampilkan dirinya sebagai duta merek yang kuat dengan memberikan nilai - nilai merek dan janji kepada pelanggan, maka mereka sudah menciptakan tingkat ekuitas merek yang tinggi di antara para pelanggan.

Teori kontrak psikologis mendukung dan menjelaskan hubungan antara IB dan OL. Teori ini menguraikan bahwa praktik-praktik IB menghasilkan hubungan dan janji bersama antara karyawan dan organisasi untuk mempertahankan manfaat yang ditawarkan masing-masing pihak, dan karyawan memastikan loyalitas sebagai imbalan atas keselamatan kerja (Hendry dan Jenkins, 1997). Pemenuhan kontrak psikologis merupakan faktor yang meningkatkan kepercayaan dan loyalitas karyawan terhadap organisasi. Dengan demikian, karyawan yang terpenuhi kontrak psikologisnya akan semakin loyal dengan organisasi dan akan lebih memilih untuk bertahan dalam organisasi daripada mencari alternatif pekerjaan lain (Santoso dan Budi, 2018).

Teori Naive Psychology Heider (2013) menjelaskan suatu perilaku. Secara akal sehat, ada dua golongan yang menjelaskan suatu perilaku; pertama, yang berasal dari orang yang bersangkutan (atribusi internal), seperti suasana hati, kepribadian, kemampuan, kondisi kesehatan, atau keinginan; kedua, yang berasal dari lingkungan atau luar diri orang yang bersangkutan (atribusi eksternal), seperti tekanan dari luar, ancaman, keadaan cuaca, ajakan/bujukan orang, ataupun pengaruh lingkungan. Teori ini mendukung dan menjelaskan bahwa perilaku pelanggan selain dipengaruhi oleh faktor internal juga dipengaruhi oleh faktor eksternal seperti pelayanan pelanggan, janji merek yang diberikan oleh organisasi dan faktor lainnya. Teori ini digunakan sebagai landasan pemikiran untuk menjelaskan pengaruh perilaku karyawan terhadap perilaku pelanggan dalam rangka mencapai ekuitas merek.

Internal branding (IB) adalah perubahan budaya yang terjadi dalam suatu organisasi ketika karyawan menjadi lebih berfokus pada pelanggan (Ind, 2017). Miles dan Mangold (2004) menyatakan bahwa IB memungkinkan perusahaan untuk secara jelas menempatkan mereknya di benak karyawan dan mendorong internalisasi karyawan terhadap nilai-nilai merek. Landasan proses yang harus tersampaikan adalah identitas merek yang terdefinisi dengan baik yang mencakup visi, nilai, dan janji merek. Dengan membuat karyawan benar-benar berkomitmen pada ideologi merek secara internal, perusahaan akan menemukan bahwa pesan merek mereka disampaikan secara eksternal jauh lebih efektif.

Internal branding dapat didukung dan ditingkatkan oleh organisasi dan sebaliknya, sehingga kesuksesan sebuah branding secara korporat tergantung cara perusahaan menerapkan dan mengintegrasikan konsep ini (Foster et al., 2010). Bagaimana perusahaan mengumpulkan data dan informasi, menganalisis dan menggunakan data dan informasi terkait untuk pengambilan keputusan yang memberikan pengaruh signifikan pada strategi secara sistematis, menjalankan strategi dengan komitmen dan konsistensi serta mengevaluasi perbaikan strategi secara terus-menerus (Sundiman, 2018). Internal branding adalah pengaturan prosedur vital yang mengatur karyawan dan memberikan mereka hak istimewa untuk membuat hubungan yang layak bagi pelanggan dengan cara yang terkendali (Apekshanirmali et al., 2017). Adanya IB dapat memastikan bahwa karyawan memahami apa arti merek dan nilai-nilai merek apa yang diusulkan perusahaan kepada pelanggan (Foster et al., 2010).

Karyawan adalah perwakilan dari merek organisasi. Karyawan adalah orang-orang yang memberikan nilai merek kepada pelanggan (Terglav, Konečnik Ruzzier, and Kaše 2016). Oleh karena itu, organisasi memiliki kebutuhan untuk mengadopsi kegiatan IB untuk menyelaraskan sikap dan perilaku karyawan dengan merek yang dikomunikasikan secara eksternal kepada pelanggan. Karyawan menyampaikan nilai dan janji merek organisasi kepada pelanggan dan memiliki dampak langsung pada pelanggan. Maria Stock et al. (2017) berpendapat bahwa perilaku karyawan, kualitas kerja dan interaksi dengan pelanggan mempengaruhi hubungan antara pelanggan dan organisasi, baik secara positif maupun negatif. Kini, CBBE mendapat pertimbangan luas dalam riset pemasaran. Penelitian tentang CBBE dalam pengaruhnya pada manajemen, karyawan dan pemasaran sudah banyak dilakukan, seperti Çifci et al. (2016); Colicev et al. (2018); Datta et al. (2017); Hasni et al. (2018); 
Irsyad (2018); Netemeyer et al. (2004); Du Preez et al. (2017).

CBBE adalah pengaruh diferensial yang dimiliki pengetahuan merek atas respon pelanggan terhadap pemasaran merek tersebut (Goyena, 2019). Persepsi pelanggan tentang fitur dan merek produk atau layanan membantu pelanggan mengenali organisasi, dikenal sebagai ekuitas merek (Kotler dan Keller, 2016). Suatu merek memiliki CBBE yang positif ketika pelanggan memiliki tertarik dan memiliki pengalaman positif terhadap suatu produk dan cara memasarkannya. Sedangkan suatu merek memiliki CBBE yang negatif jika pelanggan bereaksi kurang tertarik terhadap aktivitas pemasaran untuk merek dalam keadaan yang sama. Dalam hal ini, peran penting karyawan dalam membangun hubungan CBBE lebih ditekankan. Ini didukung oleh pendapat Jacobs (2003) bahwa karyawan yang terus-menerus berinteraksi dengan pelanggan adalah perwakilan dari kepribadian merek. Çifci et al. (2016) menganjurkan bahwa CBBE adalah elemen penting untuk mendorong niat pelanggan menuju ekuitas merek positif dalam pemikiran pelanggan. Ketika suatu organisasi berupaya meningkatkan keterampilan karyawan, karyawan memberikan kinerja yang baik secara positif memengaruhi pelanggan dan mengarah ke CBBE.

Teori keseimbangan dan teori penularan emosi mendukung hipotesis ini (Hatfield et al., 1993; Heider, 2013). Jacobs (2003) berpendapat bahwa karyawan yang terus-menerus berinteraksi dengan pelanggan adalah perwakilan dari kepribadian merek. Hasni et al. (2018) menyatakan bahwa IB membantu karyawan untuk memberikan janji merek, dan ini, sebagai imbalannya, mengarahkan pelanggan menuju ekuitas merek. Dengan adanya IB, karyawan menjadi lebih terampil dalam menyeimbangkan dan memperkuat hubungan antara organisasi dan pelanggannya karena karyawan bertindak sebagai mediator yang efektif di antara mereka.

Ketika karyawan peduli dan percaya pada merek, mereka termotivasi untuk bekerja lebih keras dan merasakan loyalitas yang lebih besar kepada perusahaan. Loyalitas organisasi karyawan ditunjukan oleh kesetiaan, kepercayaan, dan komitmen karyawan terhadap organisasi. Pengalaman merek positif dipengaruhi oleh karyawan yang benar-benar berkomitmen pada merek organisasi dan cara dalam menyampaikan merek. Ini mencerminkan gagasan IB yang efektif, yang mengusulkan bahwa baik karyawan yang berhadapan langsung dengan pelanggan maupun karyawan kantor yang tidak berhadapan langsung dengan pelanggan harus mampu dan memastikan penyampaian yang konsisten dari janji merek. Artinya, setiap karyawan di seluruh organisasi perlu memahami nilai merek perusahaan. Jika ini tercapai, dikatakan bahwa penghargaan mereka untuk peran dan komitmen mereka dalam memberikan janji merek akan meningkat juga (Heskett et al., 1994). Di sektor ritel, karyawan front-line selalu menggambarkan citra organisasi di depan pelanggan (Hasni et al., 2018). Dalam dukungan konteks ini, beberapa penelitian mendorong bahwa konteks ini akan kuat jika karyawan bekerja untuk waktu yang lama di perusahaan itu (Kim et al., 2020; Du Preez et al., 2017). Penelitian ini menjelaskan peran yang dimainkan OL dalam membangun atau memutuskan hubungan antara organisasi dan pelanggannya.

Dengan demikian, kami berhipotesis bahwa OL memediasi hubungan antara IB dan CBBE. Berdasarkan argumen di atas, dihipotesiskan bahwa:

H1. Internal Branding memiliki efek positif yang signifikan terhadap Customer-based Brand Equity.

$\mathrm{H} 2$. Internal Branding memiliki efek positif yang signifikan terhadap loyalitas organisasi.

H3. Loyalitas organisasi memiliki efek positif yang signifikan terhadap Customer-based Brand Equity.

H4. Loyalitas Organisasi memediasi hubungan antara internal branding dan Customer-based Brand Equity.

\section{Metodologi}

Lokasi penelitian ini dilakukan di kota Batam. Penelitian ini menggunakan pendekatan kuantitatif. Populasi penelitian ini adalah 81.486 UMKM ritel di kota Batam. Jumlah sampel yang diambil sebanyak 60 usaha ritel berdasarkan teori Roscoe. Teknik sampling yang digunakan oleh peneliti adalah purposive sampling, dengan pemilihan sampel dilakukan berdasarkan keputusan terhadap populasi yang memenuhi kriteria, yaitu:

1) Toko ritel yang dipilih adalah usaha ritel yang menjual produk barang.

2) Toko ritel yang dipilih adalah usaha ritel yang mempunyai karyawan front-line.

3) Jarak lokasi ritel yang dipilih adalah maksimal 10 kilometer dari tempat tinggal penulis.

4) Responden kuesioner karyawan merupakan karyawan front-line dari toko ritel di kota Batam.

5) Responden kuesioner pelanggan merupakan pelanggan yang ditunjuk oleh karyawan toko ritel terkait.

Senada dengan itu, karena keterbatasan waktu dan sumber daya manusia, ukuran sampel dari penelitian ini diambil sebanyak 60 usaha ritel dari populasi yang ada dan sudah memenuhi kriteria. Total subjek yang direkrut dalam penelitian sebanyak 60 responden karyawan dan 60 responden pelanggan. Unit analisis untuk penelitian ini adalah individu, hubungan diadik antara karyawan frontline toko ritel dan pelanggan yang ditunjuk. Penelitian ini menyelidiki faktor-faktor penerapan internal branding dalam organisasi yang mempengaruhi kinerja karyawan. Untuk menjelajahi 
faktor-faktor itu, pengalaman karyawan dan pelanggan disurvei. Karyawan yang terampil akan membentuk ekuitas merek pelanggan dan ini akan menghasilkan keberhasilan organisasi. Berdasarkan tinjauan literatur, dua kuesioner yang dikelola sendiri dikembangkan berdasarkan penelitian Hasni et al. (2018) dan Xie et al., (2014). Satu kuesioner dirancang untuk mendapatkan respons dari karyawan atas pengalaman kerja mereka sesuai dengan manajemen organisasi dan kuesioner lainnya dirancang untuk mendapatkan respons dari pelanggan atas pengalaman mereka di toko ritel. Semua tanggapan diukur menggunakan skala Likert, di mana 1 adalah sangat tidak setuju dan 5 adalah sangat setuju.

Analisis data menggunakan aplikasi SPSS 19 dan SmartPLS v.3.2.8. Analisis korelasi dilakukan menggunakan SPSS, sedangkan hubungan dan efek mediasi dikonfirmasi oleh PLS-SEM. Rincian karakteristik responden diolah dengan aplikasi SPSS 19. Responden karyawan didominasi oleh laki-laki sebanyak 37 orang $(61,7 \%)$ dan perempuan sebanyak 23 orang $(38,3 \%)$ dengan karakteristik usia sebagian besar responden berusia 26 - 35 tahun, yaitu sebanyak 33 orang (55\%) dan masa kerja sebagian responden di perusahaan selama $1-3$ tahun, yaitu sebanyak 29 orang (48,3\%). Sedangkan responden pelanggan didominasi oleh laki-laki sebanyak 28 orang $(46,7 \%)$ dan perempuan sebanya 32 orang $(53,3 \%)$ dengan karakteristik usia sebagian besar responden berusia 36 - 45 tahun, yaitu sebanyak 24 orang $(40 \%)$. Karakteristik pekerjaan sebagian besar responden pelanggan sebagian besar mempunyai profesi sebagai karyawan sebanyak 17 orang $(28,3 \%)$, dan mahasiswa sebanyak 17 orang $(28,3 \%)$ dengan banyak kunjungan ke perusahaan sebanyak 2 - 5 kali dalam setahun (cukup sering) sebanyak 22 orang $(36,7 \%)$.

\section{Hasil dan Pembahasan}

Hasil yang diperoleh dari data dengan melakukan analisis korelasi dan uji t independen sesuai dengan pertanyaan penelitian. Tabel 1 menunjukkan skala item, memuat factor loading, Cronbach's $\alpha$, composite realibility dan rata-rata varians diekstraksi (AVE) untuk semua pengukuran. Indikator KM1 tidak digunakan karena tidak cocok dan tidak sesuai dengan kriteria penelitian. Hasil nilai factor loading di atas 0,7 (Hair et al., 2017; Sarstedt et al., 2017) menunjukkan bahwa konstruk penelitian dapat menjelaskan lebih dari $50 \%$ varians indikatornya. Berdasarkan data tabel 1, diketahui bahwa masing-masing indikator variabel penelitian memiliki nilai factor loading $>0,70$ yang menunjukkan masing-masing indikator memiliki tingkat keandalan yang tinggi sudah memenuhi syarat convergent validity.

Untuk kriteria composite realibility, hasil yang berkisar antara 0,60 dan 0,70 mewakili tingkat keandalan "dapat diterima dalam penelitian eksplorasi", sedangkan hasil antara 0,70 dan 0,9 mewakili tingkat keandalan "memuaskan dan dapat digunakan dalam taham penelitian lebih lanjut", sedangkan hasil di atas 0,95 tidak diinginkan karena mengukur fenomena yang sama dan tidak mungkin menjadi ukuran yang valid dalam konstruk (Hair et al., 2017, hal. 112).

Hasil penelitian tabel 1 menunjukkan bahwa composite realibility semua variabel berada di atas 0,7 namun hanya OL yang berada di atas 0,95 dan masih dapat diterima karena menilai kriteria umum untuk mengukur composite realibility dan Cronbach's $\alpha$ adalah berkisar antara 0 dan 1, maka mengikuti nilai logika di atas 0,9 diinginkan karena mereka menunjukkan keandalan langkah-langkah yang hampir sempurna (Dr. Jan Michael Becker 2015). Untuk kriteria Cronbach's $\alpha$ yang diharapkan berdasarkan rekomendasi Sarstedt et al. (2017) adalah sama atau melebihi 0,7 .

Hasil penelitian tabel 1 menunjukkan bahwa Cronbach's $\alpha$ masing-masing variabel penelitian > 0,70. Hasil ini menunjukkan bahwa keseluruhan variabel memiliki tingkat konsistensi internal dan realibilitas yang tinggi. Nilai AVE dengan rekomendasi Hair et al. (2017) harus sama atau melebihi 0,50. Berdasarkan sajian data dalam tabel 1 , nilai AVE masing-masing variabel > 0,50 sehingga dapat dinyatakan bahwa setiap variabel memiliki discriminant validity yang baik.

Hubungan antar variabel penelitian diukur menggunakan analisis korelasi Bivariate Pearson SPSS 19. Dengan analisis diperoleh hasil kolerasi antara IB dan OL sebesar 0,797, IB dan CBBE sebesar 0,466, OL dan CBBE sebesar 0,361 sehingga terdapat hubungan kolerasi yang positif pada setiap hubungan antar variabel. Model pengukuran dan bootstrapping dilakukan dengan SmartPLS.

Tabel 2. Output Bootstrapping

\begin{tabular}{cccc}
\hline \multicolumn{2}{c}{ Hipotesis } & t-statistics & $p$-values \\
\hline $\mathrm{H} 1$ & $\mathrm{IB} \rightarrow \mathrm{CBBE}$ & 3,892 & 0,000 \\
$\mathrm{H} 2$ & $\mathrm{IB} \rightarrow \mathrm{OL}$ & 16,192 & 0,000 \\
$\mathrm{H} 3$ & OL $\rightarrow$ CBBE & 0,497 & 0,619 \\
\hline \multicolumn{4}{c}{ Sumber : SmartPLS 3. }
\end{tabular}

Berdasarkan olah data yang telah dilakukan, hasil tabel 2 dapat digunakan untuk menjawab hipotesis 1, 2 dan 3 dari penelitian ini. Proses bootstrapping dilakukan berdasarkan prosedur rekomendasi dari Hair et al. (2017) dengan menggunakan subsampel 500 dan signifikan $p$ values sebesar 0,05 . Uji hipotesis pada penelitian ini dilakukan dengan melihat nilai t-statistics dan nilai p-values. Hipotesis penelitian dapat dinyatakan diterima apabila nilai $t$-statistics $>1,96$ dan $p$ values $<0,05$. 
Berdasarkan sajian data pada tabel 2 di atas, dapat diketahui bahwa tiga hipotesis yang diajukan dalam penelitian ini, $\mathrm{H} 1$ dan $\mathrm{H} 2$ diterima karena nilai $t$-statistics $<1.96$ dan p-values $<0,05$.

Tabel 1. Skala item dan nilai pengukuran

\begin{tabular}{|c|c|c|c|c|c|}
\hline \multicolumn{2}{|r|}{ Keterangan } & \multirow[t]{2}{*}{ FL } & $\mathbf{A}$ & \multirow{2}{*}{$\begin{array}{c}\mathbf{C R} \\
0,932 \\
\end{array}$} & \multirow{2}{*}{$\begin{array}{l}\text { AVE } \\
0,663\end{array}$} \\
\hline & Internal Branding & & 0,914 & & \\
\hline B1 & $\begin{array}{l}\text { Pengarahan kerja (briefing) berisi semua informasi } \\
\text { penting bagi saya untuk memberikan layanan terbaik } \\
\text { sesuai dengan harapan perusahaan. }\end{array}$ & 0,806 & & & \\
\hline B2 & $\begin{array}{l}\text { Misi perusahaan dan janjinya terus diperkuat selama } \\
\text { pengarahan kerja. }\end{array}$ & 0,851 & & & \\
\hline $\mathrm{O} 1$ & $\begin{array}{l}\text { Program Orientasi Kerja memicu inspirasi saya untuk } \\
\text { memenuhi penyampaian janji perusahaan dengan } \\
\text { tepat. }\end{array}$ & 0,847 & & & \\
\hline $\mathrm{O} 2$ & $\begin{array}{l}\text { Saya suka program orientasi dan merek (brand) } \\
\text { perusahaan saya. }\end{array}$ & 0,910 & & & \\
\hline $\mathrm{R} 1$ & $\begin{array}{l}\text { Saya tahu persis apa yang saya harapkan dari } \\
\text { pekerjaan saya. }\end{array}$ & 0,785 & & & \\
\hline $\mathrm{R} 2$ & Saya tahu apa tanggung jawab saya. & 0,710 & & & \\
\hline \multirow[t]{2}{*}{$\mathrm{T} 1$} & $\begin{array}{l}\text { Pelatihan memberikan saya keterampilan yang tepat } \\
\text { dalam hubungan untuk menyampaikan janji yang } \\
\text { diberikan perusahaan sesuai merek usaha. }\end{array}$ & 0,776 & & & \\
\hline & CBBE (Customer-Based Brand Equity) & & 0,860 & 0,894 & 0,585 \\
\hline KM1 & $\begin{array}{l}\text { Setelah melihat perusahaan ini, saya sangat mungkin } \\
\text { akan menyukainya. }\end{array}$ & - & & & \\
\hline KM2 & $\begin{array}{l}\text { Untuk perusahaan ini, saya memiliki perasaan pribadi } \\
\text { yang positif. }\end{array}$ & 0,792 & & & \\
\hline KM3 & $\begin{array}{l}\text { Seiring waktu, saya akan semakin suka terhadap } \\
\text { perusahaan ini. }\end{array}$ & 0,821 & & & \\
\hline $\mathrm{P} 1$ & Perusahaan ini bekerja dengan baik. & 0,738 & & & \\
\hline CS1 & $\begin{array}{l}\text { Saya akan bangga untuk membeli jasa/produk dari } \\
\text { perusahaan ini. }\end{array}$ & 0,722 & & & \\
\hline $\mathrm{CS} 2$ & $\begin{array}{l}\text { Perusahaan ini sangat dihormati/dihargai oleh teman - } \\
\text { teman saya. }\end{array}$ & 0,779 & & & \\
\hline \multirow[t]{2}{*}{ CS3 } & $\begin{array}{l}\text { Dalam status dan gayanya, perusahaan ini cocok } \\
\text { dengan kepribadian saya. }\end{array}$ & 0,734 & & & \\
\hline & Loyalitas Organisasi & & 0,902 & 0,953 & 0,910 \\
\hline OL1 & $\begin{array}{l}\text { Saya akan senang menghabiskan sisa karir saya di } \\
\text { perusahaan ini. }\end{array}$ & 0,948 & & & \\
\hline OL2 & $\begin{array}{l}\text { Niat saya untuk menetap didorong oleh fakta bahwa } \\
\text { saya kompeten dalam menyampaikan Ekuitas Merek. }\end{array}$ & 0,960 & & & \\
\hline
\end{tabular}

Sedangkan H3 ditolak karena nilai $t$-statistics $<1,96$ dan $p$-values $>0,05$ yang artinya loyalitas organisasi tidak memiliki pengaruh yang signifikan terhadap CBBE.

Keterangan: FL, Factor Loading; A, Cronbach's a; CR, Composite Realibility. Sumber: SmartPLS 3.

Menurut Baron dan Kenny (1986), mediasi terjadi ketika hubungan antara variabel independen dan variabel dependen dipengaruhi oleh variabel tambahan (mediator). Mediasi terjadi bila sebuah variabel mempengaruhi hubungan antara variabel bebas dan terkait. Perubahan pada variabel bebas menyebabkan perubahan pada variabel mediator dan akhirnya menyebabkan perubahan pada variabel terikat. Mengacu pada Baron dan Kenny (1986) yang dikutip Hartono dan Abdillah (2014), pengujian efek dari variabel pemediasi dapat dilakukan jika efek utama variabel independen terhadap variabel dependen adalah signifikan. Dari hasil analisis data menggunakan SmartPLS yang disajikan di tabel 2, efek utama variabel independen terhadap variabel dependen yaitu $\mathrm{H} 1$ dan $\mathrm{H} 2$ telah terpenuhi, sehingga uji efek mediasi dapat dilakukan.

Disini, OL digunakan sebagai variabel mediator. Setelah analisis mediasi, hasil efek tidak langsung $\mathrm{IB} \rightarrow \mathrm{OL} \rightarrow \mathrm{CBBE}$ yang diperoleh adalah $t$ statistic $0,491<1,96$ dan p-values $0,624>0,05$. 
Sedangkan hasil efek langsung IB $\rightarrow \mathrm{CBBE}$ dengan $t$-statistic 5,317 > 1,96 dan p-values $0,000<0,05$. Efek langsung IB pada CBBE sebesar 5,317 lebih tinggi daripada efek tidak langsung $(0,491)$. Dari hasil tersebut bisa diartikan bahwa IB memiliki efek langsung pada CBBE dan OL tidak memediasi hubungan antara IB dan CBBE. Pernyataan ini didukung oleh $\mathrm{H} 3$, yaitu $\mathrm{OL}$ tidak memiliki pengaruh pada $\mathrm{CBBE}$, sehingga $\mathrm{H} 4$ ditolak karena loyalitas organisasi tidak memediasi hubungan antara internal branding dan Customer-based Brand Equity.

\section{Pembahasan}

Penelitian ini telah memperluas badan penelitian tentang branding dengan menguji hubungan antara internal branding, customer based brand equity, dan loyalitas organisasi. Selain itu, penelitian ini dilakukan dalam konteks negara berkembang, yaitu Kota Batam, Indonesia sehingga memperluas literatur internal branding pada konteks negara berkembang dan pemikiran maju. Hipotesis 1 penelitian ini didukung oleh hasil yang menemukan hubungan positif yang signifikan antara internal branding dan customer based brand equity. Penemuan dalam penelitian ini mengkonfirmasi penemuan Hasni et al. (2018), internal branding berpengaruh positif signifikan pada kepuasan pelanggan. Studi penelitian sebelumnya memberikan dukungan empiris yang kuat bahwa kinerja karyawan dan hasilnya langsung mempengaruhi pelanggan seperti menghasilkan ekuitas merek di pelanggan (Çifci et al., 2016; Kotler dan Keller, 2016; Punjaisri dan Wilson, 2011). Dapat disimpulkan bahwa internal branding memainkan peran penting dalam proses menghasilkan customer based brand equity. Jika manajemen mempertahankan fokus pada berbagai aspek internal branding (mis. pelatihan, kejelasan peran, orientasi, pengarahan), hal itu dapat meningkatkan produktivitas dan efisiensi kerja karyawan terutama karyawan di sektor jasa, bertindak sebagai jembatan antara organisasi dan pelanggan. Hubungan positif dan signifikan antara internal branding dan customer based brand equity dapat membantu pemasar untuk memperkirakan pentingnya internal branding dan perannya dalam menghasilkan hasil yang diinginkan (mis. Ekuitas merek) dari pelanggan untuk pertumbuhan dan manfaat jangka panjang.

Hipotesis 2 dalam penelitian ini didukung oleh hasil yang menemukan hubungan positif yang signifikan antara internal branding dan loyalitas organisasi. Penemuan dalam penelitian ini mengkonfirmasikan penemuan Hasni et al. (2018), internal branding berpengaruh positif pada loyalitas organisasi. Ketika suatu organisasi menerapkan pendekatan internal branding, itu meningkatkan tingkat loyalitas organisasi. Dengan demikian, karyawan akan merasakan keinginan yang lebih besar untuk tetap dan memperpanjang karier mereka dalam organisasi. Hasil penelitian ini menggambarkan pentingnya kualitas dalam karyawan, bahwa upaya branding dalam suatu perusahaan memperkuat dan memperpanjang hubungan karyawan dan organisasi. Kecenderungan ini telah diperhatikan oleh banyak peneliti dan memberikan hasil yang positif (Hasni et al., 2018; Helm et al., 2016; King dan Grace, 2008; Du Preez et al., 2015; Du Preez et al., 2017; Punjaisri et al., 2009; Punjaisri dan Wilson, 2011).

Hipotesis 3 dalam penelitian ini didukung oleh hasil yang menemukan tidak terdapat hubungan signifikan antara loyalitas organisasi dan customer based brand equity. Studi sebelumnya dari Hasni et al. (2018) telah menginvestigasikan bahwa karyawan yang loyal tidak hanya memahami nilainilai, janji-janji, dan hubungan organisasi dengan pelanggan tetapi juga memengaruhi ekuitas pelanggan secara signifikan dan menguntungkan. Berbeda dengan hasil temuan penelitian sebelumnya, loyalitas organisasi tidak berpengaruh secara signifikan pada customer based brand equity dalam penelitian ini. Hasil ini mungkin dikarenakan indikator-indikator yang digunakan untuk mengukur loyalitas organisasi dalam penelitian ini secara alasan teoritis tidak dapat menjelaskan langsung pengaruh loyalitas organisasi terhadap customer based brand equity dan memiliki composite realibility dari loyalitas organisasi $0,953>0,95$ sehingga indikator loyalitas organisasi lebih baik ditambah dengan beberapa dimensi seperti kepuasan kerja, lingkungan kerja, motivasi kerja, dan indikator lainnya (Al-edenat dan Alhawamdeh, 2018; Daniel dan Ashar, 2012; Nasiri et al., 2015; Tomic et al., 2018) yang dapat lebih baik dalam mengukur loyalitas organisasi dan pengaruhnya ke kepuasan dan ekuitas pelanggan (Heskett et al., 1994). Karena efek langsung dari internal branding terhadap customer based brand equity signifikan, tetapi efek tidak langsung internal branding terhadap customer based brand equity tidak signifikan, didukung oleh hubungan loyalitas organisasi terhadap customer based brand equity juga tidak signifikan, maka hubungan internal branding terhadap customer based brand equity adalah efek langsung saja tanpa pengaruh mediasi. Sehingga, Hipotesis 4 tidak dapat diterima karena loyalitas organisasi tidak memediasi hubungan internal branding dan customer based brand equity.

\section{Kesimpulan}

Akhirnya, hasil dari penelitian ini mengungkapkan bahwa internal branding memiliki dampak langsung yang signifikan dan positif pada customer based brand equity tanpa loyalitas organisasi sebagai efek mediasi. Studi ini juga menyimpulkan bahwa loyalitas karyawan tidak 
mempengaruhi hubungan karyawan-pelanggan di toko ritel Kota Batam. Efeknya terhadap ekuitas pelanggan tidak ada. Pelanggan fokus pada kinerja toko, pelayanan, dan informasi merek yang disampaikan karyawan dan tidak dipengaruhi oleh loyalitas organisasi. Studi ini menentukan bahwa internal branding memainkan peran penting dalam pengembangan karyawan dan menyelaraskan mereka dengan visi dan misi organisasi; ini menghasilkan hasil positif dalam bentuk peningkatan customer based brand equity. Sehingga bisa disimpulkan bahwa internal branding mempunyai efek langsung pada customer based brand equity tanpa memerlukan variabel loyalitas organisasi sebagai mediasi.

Saran peneliti bagi pengusaha industri ritel disarankan dapat menekankan peningkatan keterampilan kerja karyawan lewat internal branding untuk mencapai kesuksesan dalam hal ekuitas merek dengan pelanggan. Bagi peneliti lain, studi penelitian di masa depan diharapkan dapat dibuat dalam bentuk longitudinal untuk mengukur dampak jangka panjang dari internal branding terhadap customer based brand equity. Dalam penelitian masa depan, ukuran sampel harus meningkat di tingkat nasional, dan studi penelitian dilakukan pada berbagai budaya untuk meningkatkan generalisasi dari temuan penelitian. Indikator variabel loyalitas organisasi lebih baik ditambah dengan beberapa dimensi seperti kepuasan kerja, lingkungan kerja, motivasi kerja, dan indikator lain yang dapat lebih baik dalam mengukur pengaruh loyalitas organisasi terhadap customer based brand equity. Variabel mediator atau moderator lain harus diperiksa untuk memperluas pemahaman tentang hubungan antara internal branding dan customer based brand equity.

\section{Daftar Pustaka}

A. Al-edenat, Malek and Nayel Alhawamdeh. 2018. "The Mediating Effect of Employees Loyalty in the Relationship Between Empowerment and Employees Performance: A Case from Jordanian SMEs." International Journal of Academic Research in Accounting, Finance and Management Sciences 8(4):90100.

B. Apekshanirmali, K. A., Ali Khatibi, and S. M. Ferdousazam. 2017. "Internal Branding-A Conceptual Review of Related Concepts." International Journal of Scientific and Research Publications 7(8):116.

C. Aurand, Timothy W., Linda Gorchels, and Terrence R. Bishop. 2005. "Human Resource Management's Role in Internal Branding: An Opportunity for Cross-Functional Brand Message Synergy." Journal of Product and Brand Management 14(3):163-69.
D. Backhaus, Kristin and Surinder Tikoo. 2004. "Conceptualizing and Researching Employer Branding." Career Development International 9(5):501-17.

E. Badan Pusat Statistik Provinsi Kepulauan Riau. 2019. Berita Resmi Statistik BPS Provinsi Kepulauan Riau. Vol. Triwulan 3.

F. Baron, Reuben M. and David A. Kenny. 1986. "The Moderator-Mediator Variable Distinction in Social Psychological Research: Comceptual, Strategic, and Statistical Considerations." Journal of Personality and Social Psychology 51(6):1173.

G. Boukis, Achilleas, Spiros Gounaris, and Ian Lings. 2017. "Internal Market Orientation Determinants of Employee Brand Enactment." Journal of Services Marketing 31(7):690-703.

H. Çifci, Sertaç, Yuksel Ekinci, Georgina Whyatt, Arnold Japutra, Sebastian Molinillo, and Haytham Siala. 2016. "A Cross Validation of Consumer-Based Brand Equity Models: Driving Customer Equity in Retail Brands." Journal of Business Research 69(9):3740-47.

I. Colicev, Anatoli, Ashwin Malshe, and Koen Pauwels. 2018. "Social Media and CustomerBased Brand Equity: An Empirical Investigation in Retail Industry." Administrative Sciences 8(3):55.

J. Daniel, Adeel and Muhammad Ashar. 2012. "An Impact of Employee Satisfaction on Customer Satisfaction in Service Sector of Pakistan." Journal of Asian Scientific Research 2(10):548-61.

K. Datta, Hannes, Kusum L. Ailawadi, and Harald J. Van Heerde. 2017. "How Well Does Consumer-Based Brand Equity Align with Sales-Based Brand Equity and Marketing-Mix Response?” Journal of Marketing 81(3):1-20.

L. Deluxe. 2015. "6 Reasons Why a Strong Brand Is Important for Your Small Business.” Deluxe 2. Retrieved August 30, 2019 (https://www.deluxe.com/blog/six-reasonswhy-strong-brand-important-small-business/).

M. Dodo. 2019. "Kata Pengamat Ekonomi Soal Tutupnya Ritel Di Batam." Retrieved February 28, 2020 (https://www.batamnews.co.id/berita44203-kata-pengamat-ekonomi-soal-tutupnyaritel-di-batam.html). 
N. Dr. Jan Michael Becker. 2015. “Composite Relaibility - Forum.Smartpls.Com.” Forum Smartpls. Retrieved December 2, 2019 (https://forum.smartpls.com/viewtopic.php?t=3 805).

O. Foster, Carley, Khanyapuss Punjaisri, and Ranis Cheng. 2010. "Exploring the Relationship between Corporate, Internal and Employer Branding." Journal of Product and Brand Management 19(6):401-9.

P. Goyena, Rodrigo. 2019. “済無 No Title No Title." Journal of Chemical Information and Modeling 53(9):1689-99.

Q. Hair, Joseph F., Marko Sarstedt, Christian M. Ringle, and Siegfried P. Gudergan. 2017. Advanced Issues in Partial Least Squares Structural Equation Modeling. Sage Publications.

R. Hair, Joseph F., Marko Sarstedt, Christian M. Ringle, and G. T. Hult. 2017. A Primer on Partial Least Squares Structural Equation Modeling (PLS-SEM) Second Edition. Thousand Oaks: Sage.

S. Hartono, Jogiyanto and Willy Abdillah. 2014. Konsep Dan Aplikasi (Partial Least Square) Untuk Penelitian Empiris. Yogyakarta: BPFE.

T. Hasni, Muhammad Junaid Shahid, Jari Salo, Hummayoun Naeem, and Kashif Shafique Abbasi. 2018. "Impact of Internal Branding on Customer-Based Brand Equity with Mediating Effect of Organizational Loyalty: An Empirical Evidence from Retail Sector." International Journal of Retail and Distribution Management 46(11-12):1056-76.

U. Hatfield, Elaine, John T. Cacioppo, Richard L. Rapson. 1993. "Hatfield1993.Pdf." Current Directions in Psychological Science 2(3):96100.

V. Heider, Fritz. 2013. The Psychology of Interpersonal Relations. Mahwah, NJ.

W. Helm, Sabrina Verena, Uwe Renk, and Anubha Mishra. 2016. "Exploring the Impact of Employees' Self-Concept, Brand Identification and Brand Pride on Brand Citizenship Behaviors." European Journal of Marketing 50(1-2):58-77.

X. Hendry, Chris and Romy Jenkins. 1997. "Psychological Contracts and New Deals." Human Resource Management Journal
7(1):38-44.

Y. Heskett, James L., Thomas O. Jones, Gary W. Loveman, W. Earl Sasser, and Leonard A. Schlesinger. 1994. "Putting the Service-Profit Chain to Work Harvard Business Review The Service-Profit Chain." Harvard Business Review (March-April):164-74.

Z. Ind, Nicholas. 2017. Branding Inside Out: Internal Branding in Theory and Practice. Kogan Page Publishers.

AA. Irsyad, M. A. 2018. “Analisis Startup Digital IGrow Dalam Implementasi Pembangunan Ekuitas Merek Berbasis Pelanggan ( Customer Based Brand Equity )." 1-15.

BB. Jacobs, Rick. 2003. "Turn Employees into Brand Ambassadors." Bank Marketing 35(3):22-27.

CC. Keller, Kevin Lane. 2016. "Reflections on Customer-Based Brand Equity: Perspectives, Progress, and Priorities." AMS Review 6(12):1-16.

DD. Kim, Seongseop (Sam), Peter Beomcheol Kim, Seontaik Kim, and Michael Alexander Kruesi. 2020. "An Examination of the Progressive Effects of Hotel Frontline Employees' Brand Perceptions on Desirable Service Outcomes." International Journal of Hospitality Management 84(July 2019):102334.

EE. Kimpakorn, Narumon and Gerard Tocquer. 2010. "Service Brand Equity and Employee Brand Commitment." Journal of Services Marketing 24(5):378-88.

FF. King, Ceridwyn and Debra Grace. 2008. "Internal Branding: Exploring the Employee's Perspective." Journal of Brand Management 15(5):358-72.

GG. Kotler, Philip and Kevin Lane Keller. 2016. Marketing Management 15 Global Edition. Global Edi. England: Pearson Education Limited.

HH. Löhndorf, Birgit and Adamantios Diamantopoulos. 2014. "Internal Branding: Social Identity and Social Exchange Perspectives on Turning Employees into Brand Champions." Journal of Service Research 17(3):310-25.

II. Maria Stock, Ruth, Ad de Jong, and Nicolas A. Zacharias. 2017. "Frontline Employees' 
Innovative Service Behavior as Key to Customer Loyalty: Insights into FLEs' Resource Gain Spiral." Journal of Product Innovation Management 34(2):223-45.

JJ. Miles, Sandra Jeanquart and Glynn Mangold. 2004. "A Conceptualization of the Employee Branding Process." Internal Relationship Management: Linking Human Resources to Marketing Performance 3(2-3):65-87.

KK. Mude, Girish, Swapnil Undale, and Vrushali Daigavhane. 2012. "Internal Branding as a Management Strategy: A Case of Organized Retail Sector." International Journal of Research in Commerce \& Management 3(6):126-30.

LL. Nasiri, Shahram, Reza Najafbagy, and Amir Ashkan Nasiripour. 2015. "The Impact of Employee Loyalty on the Success of Commercial Organizations: A Case Study on the Dealerships of Heavy Equipment in Iran." Journal of Human Resource Management 3(3):27-32.

MM. Netemeyer, Richard G., Balaji Krishnan, Chris Pullig, Guangping Wang, Mehmet Yagci, Dwane Dean, Joe Ricks, and Ferdinand Wirth. 2004. "Developing and Validating Measures of Facets of Customer-Based Brand Equity." Journal of Business Research 57(2):209-24.

NN. Du Preez, Rose, Michael Bendixen, and Russell Abratt. 2017. "The Behavioral Consequences of Internal Brand Management among Frontline Employees." Journal of Product and Brand Management 26(3):251-61.

OO. Du Preez, Rose and Michael Thomas Bendixen. 2015. "The Impact of Internal Brand Management on Employee Job Satisfaction, Brand Commitment and Intention to Stay." Marketing Intelligence and Planning 33(1):7891.

PP. Punjaisri, Khanyapuss, Heiner Evanschitzky, and Alan Wilson. 2009. "Internal Branding: An Enabler of Employees' Brand-Supporting Behaviours." Journal of Service Management 20(2):209-26.

QQ. Punjaisri, Khanyapuss and Alan Wilson. 2007. "The Role of Internal Branding in the Delivery of Employee Brand Promise." Journal of Brand Management 15(1):57-70.

RR. Punjaisri, Khanyapuss and Alan Wilson. 2011. "Internal Branding Process: Key Mechanisms,
Outcomes and Moderating Factors." European Journal of Marketing 45(9-10):1521-37.

SS. Santoso, Asri Raditya Wardhani and C. Budi. 2018. "Pengaruh Kontrak Psikologis Terhadap Intensi Keluar Dengan Komitmen Afektif Sebagai Variabel Mediator." 4(3):464-73.

TT. Sarstedt, Marko, Christian M. Ringle, and Joseph F. Hair. 2017. Partial Least Squares Structural Equation Modeling.

UU. Sebayang, Immanuel. 2019. “Ada 81.486 Usaha Mikro Kecil Dan Menengah Di Kota Batam - Batampos.Co.Id.” Retrieved February 28, 2020 (https://batampos.co.id/2019/06/24/ada-81486-usaha-mikro-kecil-dan-menengah-di-kotabatam/).

VV. Sullivan, John. 2004. "Eights Elements of a Successful Employment Brand." Ere.Net. Retrieved (https://www.ere.net/the-8-elementsof-a-successful-employment-brand/).

WW. Sundiman, Didi. 2018. "The Effect of Knowledge Management on the Strategic Management Process Mediated By Competitive Intelligence in the Small Business Company." Jurnal Manajemen Dan Kewirausahaan 20(2):105-15.

XX. Terglav, Katja, Maja Konečnik Ruzzier, and Robert Kaše. 2016. "Internal Branding Process: Exploring the Role of Mediators in Top Management's Leadership-Commitment Relationship." International Journal of Hospitality Management 54:1-11.

YY. Tomic, Ivana, Zdravko Tesic, Bogdan Kuzmanovic, and Milos Tomic. 2018. "An Empirical Study of Employee Loyalty, Service Quality, Cost Reduction and Company Performance.” Economic Research-Ekonomska Istrazivanja 31(1):827-46.

ZZ. Utami, Wuri Putri. 2015. "Penerapan Internal Branding Pada PT. Bank Mandiri (Persero), Tbk.” Universitas Gajah Mada.

AAA. Xie, Li Shan, Jia Min Peng, and Tzung Cheng Huan. 2014. "Crafting and Testing a Central Precept in Service-Dominant Logic: Hotel Employees' Brand-Citizenship Behavior and Customers' Brand Trust." International Journal of Hospitality Management 42:1-8. 